\title{
A EXECUÇÃO FISCAL ADMINISTRATIVA: UM OLHAR SOBRE A PERSPECTIVA DA AMPLA DEFESA COMO INTEGRANTE DO FEIXE DE GARANTIAS CONSTITUCIONAIS QUE COMPÕEM O DEVIDO PROCESSO LEGAL
}

\section{Resumo}

Flávio Couto Bernardes1

Henrique Machado Rodrigues de Azevedo

O presente artigo objetiva analisar a constitucionalidade da introdução da Execução Fiscal Administrativa no contexto do ordenamento jurídico brasileiro, com foco específico na compatibilidade desse instituto com a ampla defesa, garantia constitucional elevada ao status de cláusula pétrea pela Constituição de 1988. Assim, pretende-se demonstrar que a ampla defesa é um dos aspectos do feixe de garantias que compõem o devido processo legal, devendo ser observada nos casos em que o Estado pretende se apoderar do patrimônio dos administrados pela via da tributação no contexto do paradigma do Estado Democrático de Direito, com enfoque no modelo constitucional de processo

Palavras-chave: Direito Tributário - Execução Fiscal Administrativa - Estado Democrático de Direito - Devido Processo Legal - Princípio da Ampla Defesa

\section{THE ADMINISTRATIVE FISCAL EXECUTION: A LOOK AT THE PERSPECTIVE OF THE RIGHT OF THE WIDESPREAD DEFENSE AS ONE OF THE ASPECTS THAT CONSTITUTE THE DUE PROCESS OF LAW}

\begin{abstract}
This article aims to analyze the constitutionality of introducing the Tax Administrative Execution in the context of the Brazilian legal system, with a focus in the compatibility of this Institute with the full defense principle. In this sense, it is intended to demonstrate that the full defense principle is one of the aspects that constitute the due process of law, therefore it must be observed in cases where the State intends to seize the assets of the administered by taxation in accordance with the concepts inherent in the paradigm of hermeneutics democratic State of Law, and the constitutional process model
\end{abstract}

Keywords: Tax law - Administrative Tax Execution - Law and Constitutional Democracy

1 INTRODUÇÃO

1 Professor no grupo IBMEC unidade Belo Horizonte. Graduado em Direito pela UFMG e Mestre em Direito pela PUC-MG.

Revista de Direito Tributário e Financeiro | e-ISSN: 2526-0138 | Maranhão | v. 3 | n. 2 | p. 45 -

67 | Jul/Dez. 2017. 
Inicialmente, cumpre registrar que o tema da Execução Fiscal Administrativa não é novo, muito pelo contrário, bastante tinta já foi gasta tanto por aqueles que defendem a instituição desse procedimento, quanto por aqueles que argumentam sobre sua inconstitucionalidade. De fato, na medida em que os projetos de lei que tratam dessa questão vão tendo novas movimentações em nosso Congresso Nacional, o assunto volta a ficar na mira dos holofotes, retornando para a penumbra logo em seguida, tendo em vista que não se conseguiu, até o momento, fechar a redação de um texto que pudesse ser levado à votação.

Entretanto, ainda que não se verifique uma proposta única de Execução Fiscal Administrativa a passar pelo crivo do nosso legislativo, pode-se afirmar que é possível analisar a compatibilidade entre esse procedimento e nosso ordenamento jurídico, inclusive como já realizado por diversos autores, tendo em vista a presença de um elemento comum em todos os projetos de lei sobre o tema: a concessão de poderes à administração tributária para realizar, diretamente, determinados atos de execução, tais como a constrição e a avaliação de bens.

Nesse sentido, utilizar-se-á como parâmetro para o presente estudo o Projeto de Lei $\mathrm{n}^{\circ}$ 2.412/2007, cujo autor é o deputado federal Regis de Oliveira (PSC/SP), tendo em vista que se mostra o mais abrangente, contando com o apensamento de diversos outros projetos tratando da mesma matéria. Todavia, importa ressaltar que não se analisará o referido projeto de lei detidamente, artigo por artigo, tendo em vista que o que se propõe é justamente verificar a constitucionalidade da concessão de poderes à administração tributária, ainda que por lei, para expropriar os bens dos contribuintes sem a intervenção do Poder Judiciário, em especial levando-se em consideração que a seara tributária envolve diretamente o patrimônio do cidadão; o modelo constitucional de processo instituído por nossa Carta Política e suas implicações na execução fiscal; e a abrangência da ampla defesa nesse contexto.

Quanto a esse ponto o Projeto de Lei $\mathrm{n}^{\circ}$ 2.412/2007 se encaixa perfeitamente ao objeto de trabalho ora proposto, tendo em vista que é claro ao determinar em seu art. $5^{\circ}$ que a competência para a promoção da Execução Fiscal passaria a ser do órgão da Fazenda Pública. Já em seu art. 10 dispõe que o mandado executivo emitido pelo órgão fazendário importará na 
ordem para pagar a dívida, impugná-la administrativamente ou apresentar embargos à execução ao juízo competente; bem como para penhora ou arresto e avaliação de bens².

Importante ressaltar que quase a totalidade dos defensores desse novo modelo de execução fiscal acaba adotando argumentos pragmáticos, ligados a uma apontada morosidade do Poder Judiciário, para sustentar a necessidade de transferência da competência para a prática de atos destinados à constrição de bens do Contribuinte diretamente para a administração fazendária. Argumentos nesse sentido são utilizados, inclusive, na justificação do citado PL no 2.412/2007, como se depreende do seguinte trecho:

\begin{abstract}
Esse meritório esforço não pode deixar de lado o aperfeiçoamento das ações que interessam ao Estado na qualidade de parte. Os dados hoje disponíveis comprovam, com efeito, ser o poder público o principal responsável pela sobrecarga de trabalho do Judiciário. Seja pela repetição de ações em que estão em jogo interesses homogêneos, seja pela tradição de esgotar as vias recursais, mesmo quando reconhecidamente já não há mais qualquer possibilidade de sucesso, seja pela própria estrutura da legislação processual brasileira, que por si só dificulta a tramitação, o fato é que qualquer medida que produzisse alguma racionalização dos meios por que o próprio Estado recorre ao Poder Judiciário já seria motivo de expressiva melhora, no que diz respeito à satisfação das demandas da sociedade quanto ao seu desempenho.
\end{abstract}

Entre as medidas de racionalização dos processos que sempre têm sido cogitadas, entre os que se dedicam ao estudo do tema, encontra-se o processamento administrativo das execuções fiscais. (BRASIL, 2007).

No mesmo diapasão, a própria Procuradoria-Geral da Fazenda Nacional encaminhou o Ofício n ${ }^{\circ}$ 624/2007 ao então Ministro da Fazenda com o intuito de apresentar dois modelos destinados à "diminuição da litigiosidade". Um deles trata da ampliação das possibilidades das transações administrativas e o outro fala justamente da Execução Fiscal Administrativa.

A justificativa para ambos segue a mesma linha do que restou demonstrado acima:

\footnotetext{
${ }^{2}$ Vide art. $5^{\circ}$ do PL n ${ }^{\circ}$ 2.412/2007. Disponível em: http://www.camara.gov.br/proposicoesWeb/fichadetramitacao?idProposicao=376419 . Acesso em 15/08/2017.
} 
28. Ressalte-se, ainda, que a retirada das execuções fiscais do âmbito do Poder Judiciário terá importante impacto positivo na velocidade da própria prestação jurisdicional. Como já salientado, o Poder Judiciário vive momento de grave congestionamento a impedir uma prestação jurisdicional célere. A adoção da via administrativa para a execução fiscal aliviará o Poder Judiciário de pesado fardo, liberando importantes recursos materiais e humanos que poderão ser empregados na rápida solução de lides que, hoje, levam anos para serem julgadas. (PGFN, 2007).

Em artigo específico sobre a questão, o Procurador Federal Carlos Francisco Lopes Melo defende que o modelo jurídico-social de ampliação e efetivação dos direitos fundamentais instituído pela Constituição Federal de 1988 trouxe consigo um incremento dos custos estatais que, segundo ele, seria incompatível com a execução judicial dos créditos da Fazenda Pública e complementa:

\footnotetext{
Nesse contexto, a redefinição do modelo de cobrança forçada do crédito público é um tema atual e necessário, ainda mais se for levando em conta que o estoque geral dívida ativa da União ultrapassou, no final do exercício financeiro do ano de 2009, o patamar dos oitocentos bilhões de reais ( $R$ \$ 800.000.000.000,00), enquanto que a recuperação no mesmo exercício foi de apenas dois por cento (2\%) desse valor.
}

Como alternativa para auxiliar na solução do problema do aumento do estoque da dívida ativa, surge o modelo de cobrança que se convencionou chamar de 'execução fiscal administrativa’. (MELO, 2012, p. 8)

Muito embora possa se entender como louváveis os esforços para tentar diminuir o número de processos perante o Poder Judiciário que, de tão assoberbado em nosso país ,chega a inviabilizar a prestação jurisdicional para a população em geral, não nos parece juridicamente correto utilizar esse argumento como fundamento para a defesa da introdução das Execuções Fiscais Administrativas em nosso sistema.

A uma, tendo em vista que são questionáveis os supostos avanços a serem alcançados com esse procedimento, na medida em que não se soluciona os problemas que originam a quantidade absurda de execuções fiscais distribuídas em nosso país (extrema 
complexidade da legislação tributária, quase nenhum incentivo para a realização de denúncias espontâneas, ineficiência da administração no controle de legalidade quando da lavratura das CDAs, engessamento das procuradorias no que se refere ao não ajuizamento de ações ou desistência de recursos no caso de teses contrárias à jurisprudência dominante de nossos tribunais etc.). Simplesmente o que se pretende é transferir esse problema do Poder Judiciário para a Administração Tributária como se, num passe de mágica, o Poder Executivo, com todas as suas limitações, pudesse dar vazão a toda essa gama de processos que se acumula nas prateleiras dos fóruns em todo país.

Exatamente nesse sentido são as críticas de Kiyoshi Harada, com as quais há de se concordar integralmente:

Outrossim, é preciso um mínimo de critério para a distribuição das execuções fiscais. Não faz sentido o ajuizamento em massa, misturando créditos tributários prescritos ou atingidos pelos efeitos da decadência, devedores presumivelmente insolventes ou não localizados, com créditos tributários de monta e de responsabilidade de empresas saudáveis do ponto de vista financeiro.

(...) Supor que a divisão das atividades próprias da execução fiscal entre os órgãos do Executivo e do Judiciário irá agilizar o desfecho das demandas é incorrer no equívoco elementar de quem não conhece a realidade. Como seria possível sustentar que a intervenção do Executivo poderia agilizar a execução fiscal, se os processos administrativos tributários levam, em média 36 meses para decisão final, dois quais, o contribuinte é responsável pela consumação de no máximo dois meses e meio, entre impugnação e recursos? Como um órgão administrativo, que timbra pela morosidade de seus atos, poderia agilizar a execução fiscal? Claro está que o acúmulo de executivos fiscais no Judiciário é mero pretexto para implementação de instrumentos normativos autoritários e arbitrários para arrecadar a todo custo o que fisco entende ser devido, anulando os princípios do devido processo legal e do contraditório e ampla defesa. (HARADA, 2007)

A duas, em razão de que a morosidade do Poder Judiciário e a alegada ineficiência das execuções fiscais, quando muito, poderiam ser razões para a busca de soluções alternativas, não fundamento jurídico para elas. 
Ora, defender que o modelo instituído pela Lei ${ }^{\circ}$ 6.830/80 não mais seria eficiente, sendo necessário encontrar soluções para trazer efetividade no procedimento de execução forçada de créditos tributários é uma coisa, argumentar que essa imaginada "efetividade" possa ser fundamento jurídico para defender a Execução Fiscal Administrativa é situação completamente diferente, com a qual não se pode concordar. $\mathrm{O}$ fundamento para a compatibilidade ou não desse procedimento com a Carta Política deve ser sempre jurídico, sob pena de colocarmos em risco o próprio caráter deontológico do direito, partindo-se indevidamente para uma análise meramente do que seria ou não preferível, ao invés do que deveria ser legal/constitucional.

Assim, uma defesa séria e tecnicamente admissível da Execução Fiscal Administrativa não pode deixar de passar pelo fato de demonstrar que esse procedimento não violaria direitos e garantias fundamentais do contribuinte, tais como a inafastabilidade do controle judicial (art. 50, XXXV, CF/88), o devido processo legal (art. 5, LIV, CF/88), a ampla defesa e o contraditório (art. 5, LV, CF/88).

Por outro lado, é possível encontrar argumentos que acabam por limitar o discurso, eis que se baseiam no repudio à ideia da Execução Fiscal Administrativa simplesmente por defender que o patrimônio do contribuinte não poderia ser constrito pela administração tributária, tendo em vista que tal ato seria privativo do Poder Judiciário, como se depreenderia do princípio do devido processo legal.

Ocorre, no entanto, que essa linha de argumentação fecha precocemente o diálogo, simplificando de forma indevida a questão, tendo em vista que não leva em consideração o fato de que a Carta Política vigente prevê a possibilidade do devido processo legal ser implementado no seio da administração pública, inclusive dotando esse procedimento da mesma garantia com relação à ampla defesa e ao contraditório.

Conforme lembra Carlos Francisco Lopes Melo em artigo anteriormente citado, há casos, como o da desapropriação, em que o patrimônio do administrado pode ser expropriado pelo Estado inclusive sem a participação direta do Poder Judiciário (MELO, 2012, p. 20). Nessa hipótese, a sentença simplesmente acertaria o valor da indenização caso o Estado utilize a sua prerrogativa de expropriar.

Ressalvadas as diferenças entre a desapropriação e a cobrança de créditos tributários que serão levadas em consideração no presente artigo, o que se pretende demonstrar é que a 
simples menção de violação ao princípio do devido processo legal por falta de participação do Poder Judiciário não é suficiente para afastar, de pronto, a Execução Fiscal Administrativa, caso não se vislumbre qualquer ofensa aos demais aspectos do feixe de garantias que, no paradigma do Estado Democrático de Direito, compõe esse basilar princípio constitucional.

Diante desse quadro é que se pretende analisar a questão sob a perspectiva da ampla defesa que se caracteriza justamente como um dos principais aspectos do devido processo legal e que, no caso específico da cobrança de créditos de natureza tributária, nos moldes do modelo constitucional de processo instituído pela Carta de 1988, possui particularidades que devem ser verificadas a fim de que se possa apontar a compatibilidade ou não da Execução Fiscal Administrativa com nosso ordenamento jurídico.

\section{O MODELO CONSTITUCIONAL DE PROCESSO TRIBUTÁRIO NO PARADIGMA DO ESTADO DEMOCRÁTICO DE DIREITO}

Com o advento da Constituição Federal de 1988 e tendo como pano de fundo o paradigma do Estado Democrático de Direito ${ }^{3}$, o processo deixa sua concepção de mero instrumento e passa a ser reconhecido como garantia fundamental.

Em leitura ao artigo 5ㅇ, LIV e LV da Constituição da República é notória a recepção destacada ao processo, sendo perceptível a relevância do tratamento que lhe foi conferido, tornando-se o meio democraticamente legitimador do direito.

Portanto, o processo, embasado na garantia fundamental do devido processo legal e composto de outras garantias constitucionais, dentre as quais se destacam o contraditório, a

\footnotetext{
${ }^{3} \mathrm{O}$ conceito de paradigma está intimamente ligado à obra do físico americano Thomas Kuhn, A Estrutura das Revoluções Científicas, publicada em 1963, considerada por muitos como um marco na epistemologia das ciências (KUHN, 2005). Para um maior aprofundamento sobre a aplicação do conceito de paradigma à ciência do Direito, confira-se: SOUZA CRUZ, 2009.
} 
ampla defesa, a isonomia e a fundamentação das decisões, é o meio idôneo para efetivação dos direitos fundamentais previstos na Constituição.

Sobre o processo e a Constituição, inevitável em razão de sua a importância, os autores Héctor Fix-Zamudio (BARACHO, 2008, p. 13), Ítalo Andolina e Giuseppe Vignera (CORDEIRO LEAL, 2002, p. 87), e no Brasil, destacadamente, José Alfredo de Oliveira Baracho, com a proposta de um modelo geral constitucional do processo.

Como esclarece o supracitado constitucionalista pátrio: “O processo constitucional não é apenas um direito instrumental, mas uma metodologia de garantia dos direitos fundamentais” (BARACHO, 2008, p. 57).

Dessa forma, não há outra forma de análise do tema da Execução Fiscal Administrativa sem ter como pano de fundo o Estado Democrático de Direito, bem como suas implicações no modelo constitucional de processo como metodologia de garantia dos direitos fundamentais.

Dessa forma, após as contribuições dos citados autores não é mais possível defender a noção de que apenas o direito material deveria estar em consonância com o Texto Maior. No contexto atual, o próprio processo, para efetivamente cumprir os ditames da Constituição, deve encampar os princípios ali consagrados. E tal modelo de processo constitucional abrange, por conseqüência, não apenas o processo judicial, mas também o processo legislativo e o processo administrativo, seja tributário ou não ${ }^{4}$.

Cabe ressaltar que as concepções ora defendidas têm por base, além do próprio texto expresso da Constituição, todo o caminhar evolutivo do Estado de Direito, até o contexto atual. Nesse percurso, percebeu-se que toda construção sobre os direitos individuais realizada no modelo liberal foi um avanço fundamental, mas seu simples reconhecimento formal não garantiu a autonomia privada dos cidadãos. Ademais, tornou-se possível compreender que a materialização de direitos sociais pretendida pelo Estado Social, por si só, também não garantiu a liberdade e a democracia pretendidas pelas sociedades plurais da modernidade.

Os paradigmas jurídicos que antecedem o do Estado Democrático de Direito simplesmente buscaram valorizar a pretensão de um bem-estar dos cidadãos que se apresentavam, ora como cidadãos-proprietários, num primeiro estágio, ora como cidadãos-

\footnotetext{
${ }^{4}$ A respeito do modelo constitucional de processo legislativo, confira-se: CATTONI, 2001 e DEL NEGRI, 2003. Sobre a fundamentação como princípio inerente ao processo administrativo, consultar: ARAÚJO, 1992.
} 
clientes do Estado, no segundo, mas em nenhum momento pretenderam inserí-los como atores efetivos nos processos de tomadas de decisões.

Na atualidade, o que se pretende é justamente unificar os avanços ocorridos em cada um dos paradigmas anteriores, através do reconhecimento, pelo Estado, das autonomias pública e privada dos cidadãos. Em outras palavras, busca-se a legitimidade do Direito através de procedimentos que façam com que os destinatários das normas jurídicas considerem-se, ao mesmo tempo, como seus próprios autores.

É exatamente nesse contexto que o presente estudo propõe que seja analisada a compatibilidade entre a Execução Fiscal Administrativa e nosso ordenamento, seguindo o modelo constitucional de processo e com arrimo na mais democrática participação dos agentes envolvidos na relação jurídica tributária. Tudo isso possibilitando que o Estado Arrecadador possa se valer da prerrogativa de expropriação legal do patrimônio dos contribuintes. Prerrogativa essa que somente poder ser legitimamente utilizada se não afastar o próprio contribuinte desse procedimento, a fim de que não se dizime princípios constitucionais inerentes ao paradigma do Estado Democrático de Direito, tais como a ampla defesa, o contraditório, a isonomia e a garantia da propriedade privada.

Como ressaltado na introdução, a simples afirmativa que o devido processo legal previsto no artigo 5, LIV da CF/88 impediria que o Poder Executivo, por si só, pudesse realizar atos relacionados com a expropriação dos contribuintes não parece encerrar adequadamente a questão como pretendem seus defensores. Isso porque, levando-se o modelo constitucional de processo a sério, é possível verificar que a Carta Política também garantiu aos litigantes na seara administrativa em geral o pleno exercício da ampla defesa e do contraditório. Em outras palavras, o devido processo legal também pode ser, em tese, exercido na esfera administrativa.

Seguindo as premissas acima, caso efetivamente estejam respeitadas as garantias constitucionais do contribuinte, possibilitando a sua irrestrita participação no discurso, não se poderia afirmar que o devido processo legal não estaria sendo respeitado na esfera administrativa, ou seja, a princípio, inexistiria incompatibilidade entre a Execução Fiscal Administrativa e nosso ordenamento jurídico. 
Assim, nessa hipótese, o devido processo legal estaria sendo respeitado, o que possibilitaria a expropriação do patrimônio do contribuinte, nos termos do próprio inciso LIV, do art. $5^{\circ}$ da Constituição.

Por outro lado, o princípio da inafastabilidade da tutela jurisdicional (art. $5^{\circ}$, inciso $\mathrm{XXXV}$, da $\mathrm{CF} / 88$ ) também não estaria sendo violado, tendo em vista que, a qualquer momento, esse mesmo Contribuinte poderia recorrer ao Poder Judiciário para discutir possíveis ilegalidades ou inconstitucionalidades no procedimento.

Todavia, tais observações somente servem para afastar o argumento de que o devido processo legal, por si só, impossibilitaria a Execução Fiscal Administrativa. É que a questão não pode ser analisada apenas em tese, como realizado acima, é preciso um olhar mais aprofundado sobre o tema, em especial levando-se em consideração aspectos como a própria formação do título executivo na seara tributária (a CDA).

Dito de outro modo, o devido processo legal, desde que observado o modelo constitucional de processo, possibilitando a efetiva participação do administrado, é capaz, até mesmo, de constitucionalmente autorizar a expropriação de seus bens em alguns casos. Todavia, na seara específica da tributação, tendo em vista as particularidades da inscrição em dívida ativa, tal afirmação não pode validamente ser defendida sem que antes se verifique se realmente nessas hipóteses resta garantido ao contribuinte o pleno exercício da ampla defesa.

\section{A AMPLA DEFESA COMO ASPECTO FUNDAMENTAL DO FEIXE DE GARANTIAS QUE COMPÕEM O DEVIDO PROCESSO LEGAL}

Como frisado acima, a Constituição garante aos cidadãos que sua propriedade não será afetada sem a plena observância do devido processo legal, garantia essa aplicável não só aos litigantes na via judicial, mas também na administrativa. Portanto, no modelo constitucional de processo, o devido processo legal é fundamental inclusive perante a administração tributária.

Exatamente nesse sentido, em obra específica sobre o processo tributário administrativo, Lídia Maria Lopes Rodrigues Ribas assevera que:

(...) a cláusula do devido processo legal é destinada a tutelar direito, ou seja, é o meio pela qual devem ser reconhecidos, preservados ou cumpridos os direitos 
substantivos, que no processo administrativo tributário se confirmam se a participação do interessado se der no mesmo plano de posições jurídicas que a Administração quanto às faculdades, ônus e direitos. Assim, o devido processo legal visa a garantir o direito de ação, a igualdade das partes e o respeito ao direito de defesa e ao contraditório. (...) Estes requisitos é que efetivamente dão conteúdo e materialidade ao devido processo legal, na medida em que viabilizam o direito de defesa, do qual são titulares os administrados, quando sentem seus direitos ofendidos pelo Poder Público. (RIBAS, 2008, p.42-43)

Eduardo Domingos Bottallo também ressalta a impossibilidade de se afastar, no paradigma atual, o processo tributário administrativo da garantia ao pleno exercício do devido processo legal:

\begin{abstract}
Esta, pois a dimensão principiológica da cláusula, cuja acolhida pelo contencioso administrativo garante a adequada proteção dos direitos subjetivos de que são titulares todos quantos se vejam postos em confronto com a ação do Estado.

(...) Por ora, cabe reafirmar que a presença do due process of law na estrutura e na dinâmica operacional do processo administrativo tributário afigura-se essencial e inafastável, porque sem ela tal processo se mostra imprestável para a tutela de direitos e ineficaz como garantia para a distribuição do justo legal. (BOTALLO, 2006, p. 43)
\end{abstract}

Firmada essa premissa, quer dizer, da inexorável necessidade de observância do devido processo legal tanto na esfera judicial, quanto na administrativa, importante analisar o conteúdo dessa garantia, em especial no que se refere ao papel da ampla defesa. Isso porque, alegar que a Execução Fiscal Administrativa ofenderia o art. 5², inciso LIV da Constituição simplesmente por permitir que a Administração Tributária pratique atos relacionados com a expropriação do patrimônio do contribuinte não é suficiente, por si só, para culminar na incompatibilidade desse procedimento com nosso ordenamento. A final de contas cabe reiterar que é possível, em alguns casos, a plena observância do devido processo legal na seara administrativa, sem a participação do Poder Judiciário. 
O que deve ser verificado, portanto, é se, no campo específico da tributação, o devido processo legal seria respeitado de forma plena no contexto da Execução Fiscal Administrativa, quer dizer, se todas as garantias a ele inerentes seriam observadas nesse caso, em especial no que tange à ampla defesa.

Nesse sentido, adotam-se sem ressalvas as considerações de Alexandre Mariotti formuladas em sua dissertação específica sobre o tema do devido processo legal, em especial a respeito de que essa garantia não se resume à dicção literal apenas do inciso LIV, do art. $5^{\circ}$ da Constituição da República:

A referência reiterada ao inciso LIV do art. $5^{\circ}$ da CRFB não deve ser entendida como significando que a definição dos contornos do devido processo legal possa ser feita unicamente à vista desse dispositivo. Para além do que é óbvio - partir do texto não implica identificação entre texto e norma -, esse destaque não implica perder de vista que esse dispositivo é parte de um sistema, tanto no sentido restrito de parte de um mesmo diploma normativo, quanto no sentido amplo de elemento de uma ordem jurídica. De fato, como alerta Claus-Wilhelm Canaris ao defender a importância da noção de sistema em Direito, "só a ordenação sistemática permite entender a norma questionada não apenas como um fenômeno isolado, mas como parte de um todo".

Falar a sério sobre devido processo legal implica, pois, situar a norma dentro da CRFB e, em um sentido mais amplo, dentro do ordenamento jurídico brasileiro, que nela não se esgota. Embora não se possa, na realidade, separar inteiramente os dois contextos, o presente estudo focará o devido processo legal dentro do primeiro deles, ou seja, em relação à CRFB. (MARIOTTI, 2008, p. 36-37)

De fato, o devido processo legal representa a "protetividade dos direitos" 5 do cidadão em sentido amplo, constituindo-se de um conjunto de garantias constitucionais capazes de formar um feixe suficientemente forte para coibir abusos do poder público de um lado e possibilitar, de outro, a participação dialética dos administrados na construção das decisões.

E continua Alexandre Mariotti ressaltando o papel do devido processo legal como a “fórmula-síntese da proteção constitucional da liberdade e dos bens da pessoa, articulando

\footnotetext{
${ }^{5}$ Expressão utilizada por Humberto Ávila (ÁVILA, 2008, p. 114).
} 
as outras garantias constitucionais com vista e esse fim último que lhes é comum" (MARIOTTI, 2008, p. 102).

Desse modo, não há dúvidas sobre o papel fundamental da ampla defesa no conjunto de garantias que constitui o devido processo legal, não havendo que se falar em sua efetiva observância se, por qualquer aspecto, o contribuinte tenha seu direito de garantia mitigado.

De fato, ambas as garantias constitucionais, no contexto do paradigma atual, se complementam, não havendo que se falar que a ampla defesa pode ser exercida fora do contexto do devido processo legal, nem mesmo em observância do devido processo legal com mitigação da ampla defesa.

Ademais cumpre frisar que não há mais espaço para a compreensão do devido processo legal e das demais garantias a ele inerentes como meras orientações advindas da Constituição, pelo contrário, todo o esforço do constitucionalismo moderno se volta justamente a conferir força normativa (cogente) aos primados constantes do Texto Maior.

Tendo como orientação o paradigma atual, é possível afirmar que a interpretação dos princípios como mandamentos meramente norteadores não se adequa à hermenêutica constitucional contemporânea. A derrocada do Estado Social e suas promessas culminaram no afastamento das doutrinas baseadas em normas meramente programáticas, já combatidas pelo célebre constitucionalista português Joaquim José Gomes Canotilho. Todavia, importa frisar que o próprio Canotilho, na segunda edição de sua obra "Constituição dirigente e vinculação do legislador”, parece rever sua teoria, adotando um modelo denominado de “constitucionalismo moralmente reflexivo” (CANOTILHO, 2001), justamente por defender que a Constituição não será plenamente respeitada enquanto suas normas forem entendidas como meros programas, ou mesmo como simples e diretas ordens. O mundo atual, cabe reiterar, demanda a participação da sociedade como efetivos atores, sendo essa a forma de conferir legitimidade ao Direito, fato que eleva o processo ao fundamental papel de nortear o discurso jurídico.

Logo, um dos pilares para a compreensão do processo constitucionalizado é reconhecer a força cogente das normas constitucionais, em especial os direitos e garantias fundamentais do cidadão, sendo, portanto, incabíveis quaisquer interpretações que limitem o 
devido processo legal e quaisquer das demais garantias que o compõem, em especial para o caso em análise, a ampla defesa ${ }^{6}$.

\section{A EXECUÇÃO FISCAL ADMINISTRATIVA E O PRINCÍPIO DA AMPLA DEFESA}

Feitas as considerações acima, ressalta-se que a análise da compatibilidade da Execução Fiscal Administrativa com nosso ordenamento jurídico pena inequivocamente pelo princípio $^{7}$ da ampla defesa, ou seja, restando demonstrado que algum aspecto dessa garantia constitucional foi mitigado, não há que se falar na possibilidade jurídica da instauração desse procedimento.

Ora, nos termos mencionados acima, verifica-se, em alguns casos, que o devido processo legal é plenamente respeitado na esfera administrativa. Todavia, há de se determinar se na hipótese da cobrança de crédito tributário já definitivamente constituído essa premissa é confirmada, sendo que o cerne da questão passa justamente por um dos aspectos que compõem o devido processo legal como um todo: a ampla defesa.

A questão passa, por conseguinte, por saber se a Execução Fiscal Administrativa propicia efetivamente o exercício da ampla defesa.

\subsection{A Formação do Crédito Tributário, a Unilateralidade da CDA e suas Consequências Jurídicas}

No Brasil, conforme o Código Tributário Nacional, o crédito tributário tem origem com a ocorrência do fato gerador, isto é, a concretização da hipótese de incidência tributária, como elemento integrante da obrigação tributária (objeto), como dispõe o art. 113. No entanto, o cumprimento do dever jurídico de seu recolhimento por parte do sujeito passivo,

\footnotetext{
${ }^{6}$ Nesse sentido: LEAL, 2005, p. 112.

${ }^{7}$ Não se destina o presente trabalho a aprofundar o debate entre a distinção entre princípios e regras, eis que as limitações do objeto de estudo impõem tal corte metodológico. Contudo, concorda-se com Souza Cruz em sua colocação de que o intérprete, ao aplicar o Direito, deve levar em consideração o seu todo e não apenas as regras prima facie contraditórias em um conflito de regras ou os princípios colidentes em um conflito de princípios. (SOUZA CRUZ, 2007, p. 310). Dessa forma, a nomenclatura princípio da ampla defesa é utilizada em decorrência da costumeira utilização da doutrina pátria, sendo apenas importante ressaltar que se trata de norma jurídica, de hierarquia constitucional, portanto com força cogente.
} 
bem como sua exigibilidade pela Administração Fazendária, dependerá da modalidade de lançamento estabelecido pela lei para a formalização do crédito tributário. Vislumbra-se, assim, que o procedimento tributário administrativo poderá adotar diferentes diretrizes, todas em conformidade com a lei, quando observada as referidas variáveis.

Formalizado o crédito tributário e não satisfeita a obrigação pelo sujeito passivo, caso este não venha a questionar sua exigência perante a própria administração pública, pedindo a revisão do ato administrativo de lançamento, ou não lhe sendo permitido o exercício de seu direito de defesa (como no caso do malsinado crédito tributário "não contencioso”), o crédito tributário será inscrito em dívida ativa para a posterior emissão do título executivo. Caso contrário, interpondo sua impugnação administrativa, instaura-se a fase contenciosa do procedimento, cuja tramitação deve ser verificada no ordenamento jurídico de cada país.

A formação deste litígio instaura a etapa do procedimento denominada de contencioso administrativo fiscal. O cidadão-contribuinte, a partir da comunicação da administração pública quanto à exigência de certa prestação que interfere no seu conjunto de bens e direitos, pode se opor à pretensão estatal na hipótese de discordar de seus fundamentos. O direito de manifestar sua discordância possibilita o exercício da ampla defesa, que constitui garantia assegurada a todo cidadão nas democracias modernas, essencial para a legitimidade da formação do título executivo de natureza tributária.

Sendo assim, concluída a formalização definitiva do crédito tributário, pelo encerramento do contencioso administrativo fiscal de forma favorável à Administração Fazendária, ou pelo não questionamento do ato de lançamento pelo sujeito passivo obrigacional, prossegue-se o desenvolvimento do aspecto procedimental da norma jurídica tributária, com a inscrição do valor devido na denominada dívida ativa tributária. Tal procedimento permite a extração do título executivo, que servirá como título executivo extrajudicial para o ajuizamento da ação judicial apropriada, denominada no direito brasileiro de execução fiscal, justamente o cerne da discussão em tela.

Constata-se, portanto, que a formação do título executivo decorre da continuidade da relação jurídica tributária de direito material, através, obrigatoriamente, do procedimento administrativo, que poderá ser contencioso ou não. Realizado o ato de lançamento e existindo 
a manifestação de inconformidade do sujeito passivo, através do exercício da ampla defesa pelo direito de petição, haverá a fase contenciosa do procedimento administrativo, já mencionada. Na hipótese do crédito tributário designado de não contencioso ou da não interposição do recurso administrativo por parte do devedor, haverá a automática formalização definitiva do crédito tributário, com sua inscrição na dívida ativa tributária.

Indiscutível, assim, que o título executivo tributário, intitulado na legislação brasileira de Certidão da Dívida Ativa, reproduzindo os elementos que motivaram a inscrição na dívida ativa tributária, formaliza-se de forma unilateral, sem a necessidade da anuência do sujeito passivo, mas pela mera observância das formalidades legais pelo credor da obrigação. Esta particularidade caracteriza a especificidade da obrigação tributária, tornando-a especial em virtude de seu objeto e de seu devedor ${ }^{8}$.

Cumpre frisar, então, que a unilateralidade formação do título executivo no caso de créditos tributários devidamente constituídos, ou seja, da Certidão de Dívida Ativa (CDA), possui consequência direta no tema, tendo em vista que se pretende justamente transferir para o credor a possibilidade de manejar procedimentos destinados à constrição do patrimônio do devedor.

Em outras palavras, especificamente no caso em comento, o Fisco passaria a deter poderes para não só constituir o crédito tributário pela via do lançamento, mas torná-lo definitivo através do contencioso administrativo tributário ${ }^{9}$, constituir unilateralmente o título executivo respectivo e, por fim, realizar atos no sentido de avançar no patrimônio do contribuinte, o que sem sombra de dúvidas acaba por infringir diretamente o princípio da ampla defesa.

Sob esse aspecto, o que se verifica é a possibilidade de transferência patrimonial do contribuinte para o Fisco $^{10}$, sem qualquer manifestação de concordância do devedor e,

\footnotetext{
${ }^{8}$ Confira-se: COÊLHO, 1999, p. 188.

${ }^{9}$ Salienta-se que por mais que nossa Carta Política garanta o exercício da ampla defesa no contencioso administrativo tributário, fato é que a submissão direta dos Tribunais Administrativos à Administração Tributária e a existência de privilégios à Fazenda Pública, tais como recursos hierárquicos, voto de qualidade, dentre outros, mitiga completamente a autonomia desses procedimentos.

${ }^{10}$ Vide, a título exemplificativo, o art. 16 do Projeto de Lei no $2.412 / 2007$ :

"Art. 16. Se a penhora efetuar-se em dinheiro, o valor penhorado converter-se-á, de logo, em renda da Fazenda Pública.”
} 
evidentemente, como total interesse do credor, sem o crivo imparcial e equidistante do Poder Judiciário, o que seria fundamental nesse caso.

Insta salientar que há casos ainda mais graves, ou seja, hipóteses em que o contribuinte sequer teve condições de exercer a ampla defesa na esfera administrativa, como nos chamados créditos tributários "não contenciosos". Nessas hipóteses, nem mesmo é facultado ao devedor impugnar o lançamento, sendo que o crédito tributário é definitivamente constituído pela simples declaração do sujeito passivo, sem passar procedimento administrativo, etapa fundamental de sua constituição ${ }^{11}$.

Entender que a Execução Fiscal Administrativa é compatível com o ordenamento jurídico em casos como o dos créditos tributários não contenciosos é admitir que uma declaração prestada pelo sujeito passivo pudesse permitir, por si só, que seu patrimônio seja constrito sem a intervenção do Poder Judiciário.

\subsection{Da Impossibilidade de Total Supressão do Contraditório no Processo de Execução Fiscal e do Consequente Cerceamento do Direito de Defesa na Execução Fiscal Administrativa}

Outro importante ponto que deve ser ressaltado é que os defensores da Execução Fiscal Administrativa baseiam-se em premissa totalmente equivocada, eis que incompatível como o modelo constitucional de processo, quer dizer, a completa inexistência de contraditório no processo de execução fiscal.

Nesse sentido, confira-se trecho do já anteriormente citado artigo de Carlos Francisco Lopes Melo:

\footnotetext{
O que os projetos inovam em termos de cobrança da dívida ativa é a transferência para a Fazenda Pública dos atos que são executados pelos agentes auxiliares do juiz, como os atos do oficial de justiça, responsável pela realizada da penhora e o arresto, e os atos da alienação pública. Todas e quaisquer decisões, seja sobre a dívida, seja sobre o procedimento, permanecem sujeitos à apreciação judicial.
}

\footnotetext{
${ }^{11}$ Nesse sentido confira-se: NOGUEIRA, 1995 e ALMEIDA JÚNIOR 1998.
} 
Evita-se, portanto, a judicialização prévia para a realização de atos que não requerem a participação pessoal do magistrado (MELO, 2012, p. 21).

Na verdade, no contexto do paradigma atual e utilizando como premissa a adoção, pela Constituição Federal, do modelo constitucional de processo, não há que se falar em relação processual sem a possibilidade do contraditório, assim entendido em sua concepção ampla, relacionada com a igualdade de oportunidades e não apenas o direito de dizer ou contradizer.

Em artigo específico sobre os fundamentos constitucionais da execução fiscal Charley Teixeira Chaves defende com propriedade que:

A desculpa de não existir contraditório na execução fiscal deve-se ao fato de o Direito já estar pré-acertado (jurisatisfativa), é o mesmo que ignorar a compreensão do que representa tal princípio. O contraditório é a igualdade de oportunidade no processo, é a condizente oportunidade de igualdade de tratamento, que se funda na liberdade de todos perante a lei.

(...) Por oportuno, pede-se vênia para se discordar daqueles que, mesmo defendendo a presença de contraditório na execução, fazem-no de forma reduzida ou atenuada. O contrário senso afirma que o contraditório é amplo, trata-se de igualdade de oportunidade no procedimento e não é necessário que se fale da imprescindibilidade da discussão do seu conteúdo material para materializá-lo. O contraditório ultrapassa as expectativas de discussão sobre determinado conteúdo, “podendo, até mesmo, exercer a liberdade de nada dizerem (silêncio), embora tendo direito-garantia de se manifestarem” (LEAL, 2004, p. 167); efetiva-se, assim, a garantia do contraditório, exercido pela liberdade de manifestar-se ou não, logicamente respondendo pelo ônus processual de seus atos.

(...) Muitos acreditam que o contraditório se realiza apenas via Embargos de Devedor, processo autônomo, na expressão de Liebman, ação incidente (2003). Veja que a Constituição da República Federativa do Brasil de 1988 não delimitou a qual processo (leia-se procedimento) deve ser assegurado o contraditório. Na verdade, a partir da leitura do art. 5 LV, CR/88 se extrai a presença do contraditório em todos os processos, inclusive no executivo (CHAVES, 2012, p. 8). 
Nesse sentido, há possibilidade de contraditório e, portanto, atividade cognitiva no seio da Execução Fiscal, ainda que essa cognição se apresente de maneira mais restritiva do que ocorre no processo de conhecimento. Diversas questões podem ser suscitadas pelas partes no intuito de obterem um posicionamento efetivamente decisório por parte do Poder Judiciário, antes mesmo da constrição dos bens do devedor.

Somente as questões de ordem pública, portanto passíveis de serem conhecidas de ofício, já seriam suficientes para demonstrar a mitigação do direito de defesa do contribuinte caso atos destinados à constrição de seu patrimônio sejam realizados diretamente pela Administração Tributária, sem a intervenção de um juiz natural.

Imagine-se, por exemplo, o caso da decadência tributária. Quanto a essa questão o Superior Tribunal de Justiça já firmou, na Súmula $n^{0} 555$, que nos tributos submetidos ao lançamento por homologação, não tendo o sujeito passivo declarado o débito, aplicar-se-ia o art. 173, inciso I, do CTN para a contagem do prazo decadencial.

Interpretando esse enunciado, restou definido, então, que quando o sujeito passivo declara o montante que entendeu devido, mas recolhe valor que o Fisco considera inferior ao correto, a contagem do prazo decadencial se submeteria ao art. 150 , § $4^{\circ}$ do CTN $^{12}$.

Ocorre, entretanto, que o Conselho de Contribuintes, apesar da matéria encontra-se sumulada pelo STJ, possui jurisprudência dominante no sentido de que, para lançamento de ofício, o prazo decadencial deveria ser contado nos termos do art. 173, I do CTN, independentemente de ter havido ou não pagamento parcial do tributo ${ }^{13}$.

Em casos como esse, em nada adiantaria a possibilidade de uma impugnação administrativa posterior à constituição definitiva do crédito tributário, mas anterior à penhora, justamente destinada a tratar de questões de ordem pública ${ }^{14}$. A ausência de manifestação do Poder Judiciário implica ofensa direta à ampla defesa capaz de tornar incompatível o procedimento da Execução Fiscal Administrativa com o ordenamento jurídico pátrio.

\footnotetext{
${ }^{12}$ Confira-se: STJ - AgRg no REsp 1277854/PR, Rel. Ministro HUMBERTO MARTINS, SEGUNDA TURMA, julgado em 12/06/2012, DJe 18/06/2012)

${ }^{13}$ A título exemplificativo, entre inúmeros outros, confira-se o Acórdão: 4.809/17/CE, proferido pela Câmara Especial do CCMG e publicado em 09/06/2017.

${ }^{14}$ Nesse diapasão, veja-se o art. 10, inciso I, do PL no 2.412/2007.
} 
Vários outros são os exemplos de questões juridicamente passíveis de serem levantadas em sede de Execução Fiscal e que, portanto, necessitam de provimento judicial, sob pena de mitigação da ampla defesa e, consequentemente, em infringência ao devido processo legal, capaz de impossibilitar a constrição do patrimônio do contribuinte diretamente pela Administração Tributária. A questão do redirecionamento da execução é mais um caso.

Ora, nos termos da jurisprudência do STJ, quando o nome de um suposto responsável tributário não constar expressamente da CDA, não é possível o mero redirecionamento da execução fiscal. Nessas hipóteses caberia à fazenda demonstrar, no caso de pessoa física, que esta incorreu em uma das hipóteses do art. 135, inciso III, do CTN ou tenha ocorrido dissolução irregular da sociedade ${ }^{15}$.

Entretanto, resta evidente que no caso da Execução Fiscal Administrativa, essa discussão ofenderia claramente a ampla defesa. Isso, tendo em vista que seria travada perante a própria Administração Tributária que, conforme salientado acima, efetuou o lançamento, tornou-o definitivamente constituído através do contencioso administrativo, lavrou unilateralmente a CDA e, nessa hipótese, decidiria pela existência ou não de evento posterior causador da responsabilidade tributária de terceiros.

\section{CONCLUSÃO}

Em razão dos argumentos expostos no presente trabalho, conclui-se, levando-se em consideração o paradigma do Estado Democrático de Direito e o modelo constitucional de processo, pela incompatibilidade entre a Execução Fiscal Administrativa e o ordenamento jurídico pátrio.

Primeiramente rechaçou-se a fundamentação desse procedimento através de argumentos relacionados com a ineficiência da execução fiscal pela via judicial. Primeiramente em razão de que não se estaria atacando a origem do problema, bem como em decorrência de serem questionáveis os ganhos de eficiência com a sua implementação, tendo em vista a conhecida ausência de estrutura das Administrações Tributárias em nosso país.

\footnotetext{
${ }^{15}$ Veja-se: STJ - REsp 1455490/PR, Rel. Ministro HERMAN BENJAMIN, SEGUNDA TURMA, julgado em 26/08/2014, DJe 25/09/2014.
} 
Em segundo lugar, salientou-se que, ainda que fosse possível culpar o procedimento judicial para ineficiência da arrecadação, tal fato não seria suficiente para fundamentar, em termos jurídicos, a Execução Fiscal Administrativa. Quando muito se trataria de um motivo para a busca de soluções que respeitassem os direitos e garantias fundamentais do cidadão, em especial aquelas inerentes ao modelo constitucional de processo.

Ademais, restou demonstrado que há situações jurídicas em que o devido processo legal é completamente respeitado na seara administrativa, de forma que o art. $5^{\circ}$, LIV da Constituição de 1988 estaria obedecido, possibilitando que o poder público se aproprie do patrimônio do administrado.

Contudo, especificamente nas hipóteses de cobrança de créditos tributários definitivamente constituídos, o pleno respeito ao devido processo legal não se verifica sem a participação do Poder Judiciário nos atos relacionados à constrição do patrimônio do contribuinte. Nesses casos, tendo em vista as particularidades da dívida ativa e de sua constituição, a Execução Fiscal Administrativa acaba por infringir a ampla defesa do devedor, aspecto esse fundamental do feixe de garantias que compõem o devido processo legal.

Assim, considerando que a garantia da ampla defesa para o contribuinte restará mitigada caso seu patrimônio seja constrito pela Administração Tributária sem a interseção de um juiz natural, fica comprovada a incompatibilidade entre a Execução Fiscal Administrativa (nos moldes em que vem sendo pretendida nos projetos de lei até então apresentados) e nosso ordenamento jurídico.

Configura-se, portanto, como completamente incompatível com o paradigma atual, considerando-se a demonstrada unilateralidade da CDA, o fato do mesmo ente público lançar o tributo, tornar definitivamente constituído o crédito tributário, lavrar o respectivo título executivo e ainda praticar atos tendentes à constrição do patrimônio do contribuinte.

E mais não se amolda ao conceito constitucional de processo a negativa da existência de contraditório e de cognição (ainda que restrita) no processo de execução fiscal como premissa para a defesa da Execução Fiscal Administrativa. Conforme demonstrado, há uma imensa gama de discussões passíveis de serem travadas antes mesmo da constrição do patrimônio do contribuinte e que, caso tenham que ser levadas unicamente ao Poder Executivo, implicarão em grave violação à ampla defesa. 


\section{REFERÊNCIAS BIBLIOGRÁFICAS}

ALMEIDA JÚNIOR, Fernando Osório. A confissão de dívida fiscal - meio hábil ao surgimento da obrigação tributária. Revista Dialética de Direito Tributário, v. 32, 1998.

ANDOLINA, Italo; VIGNERA, Giuseppe. Il modello costitucionale del proceso civil italiano. G. Giappicheli, Editore, Torino, 1990.

ARAÚJO, Florivaldo Dutra de. Motivação e Controle do Ato Administrativo. Belo Horizonte: Del Rey, 1992.

ÁVILA, Humberto. Sistema Constitucional Tributário: de acordo com a emenda constitucional n 53, de 19.12.06. $3^{\text {a }}$ ed. rev. e atual. São Paulo: Saraiva, 2008.

BARACHO, José Alfredo de. Processo Constitucional. $1^{\text {a }}$ reimpressão. Belo Horizonte: Fórum, 2008.

BARACHO, José Alfredo de. Processo Constitucional. Revista Forense v. 337, p.105-123, Rio de Janeiro, jan/mar 1997.

BONILHA, Paulo Celso B. Da Prova no Processo Administrativo Tributário. São Paulo: LTR, 1992.

BOTALLO, Eduardo Domingos. Curso de Processo Administrativo Tributário, $2^{\mathrm{a}}$ ed., São Paulo: Malheiros Editores, 2009.

CANOTILHO, José Joaquim Gomes. Constituição dirigente e vinculação do legislador. $2^{\mathrm{a}}$ ed. Coimbra: Coimbra. 2001.

CHAVES, Charley Teixeira. Fundamentos constitucionais da execução fiscal e da execução contra a fazenda pública. 2012. Disponível em: https://aplicacao.mpmg.mp.br/xmlui/bitstream/handle/123456789/1061/2\%20R\%20DJ\%20F undamentos\%20constitucionais\%20-\%20charley.pdf?sequence=1 . Acesso em 15.08.2017. 
COÊLHO, Sacha Calmon Navarro. Processo administrativo tributário. in: MARTINS, Ives Gandra da Silva (Coord.). Processo administrativo tributário. São Paulo: Revista dos Tribunais, 1999.

CORDEIRO LEAL, André. O Contraditório e a Fundamentação das Decisões. Belo Horizonte: Mandamentos, 2002.

DEL NEGRI, André. Controle de Constitucionalidade no Processo Legislativo, $1^{\text {a }}$ ed. Fórum, Belo Horizonte, 2003.

GONÇALVES, Aroldo Plínio. Técnica Processual e Teoria do Processo. $1^{\mathrm{a}}$ ed. $2^{\mathrm{a}}$ tiragem. Rio de Janeiro: Aide, 2001.

HARADA, Kiyoshi. Execução Fiscal. Exame do Anteprojeto. 2007. Disponível em: http://artigoscheckpoint.thomsonreuters.com.br/a/39cp/execucao-fiscal-exame-doanteprojeto-kiyoshi-harada. Acesso em 05/08/2017.

KUHN, Thomas. A estrutura das revoluções científicas. Trad. Beatriz e Nelson Boeira, $7^{\mathrm{a}}$ ed., São Paulo: Perspectiva, 2005.

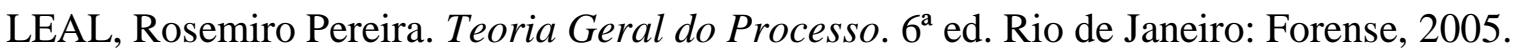

MARIOTTI, Alexandre. Princípio do devido processo legal. 2008. 131 f. Tese (Doutorado) Programa de Pós-Graduação em Direito, Universidade Federal do Rio Grande do Sul, Porto Alegre, 2008, p. 36-37. Disponível em: http://hdl.handle.net/10183/13555. Aceso em: 05/08/2017.

MELO, Carlos Francisco Lopes. "Execução fiscal administrativa à luz da Constituição Federal”. Disponível em: http://www.agu.gov.br/page/download/index/id/8356880. Acesso em 05.07.2017.

OLIVEIRA, Marcelo A. Cattoni de. Devido Processo Legislativo. Belo Horizonte: Mandamentos, 2001. 
RIBAS, Lídia Maria Lopes Rodrigues. Processo Administrativo Tributário. $3^{\mathrm{a}}$ ed. São Paulo: Malheiros Editores, 2008.

SOUZA CRUZ, Álvaro Ricardo. O Discurso Científico na modernidade: o conceito de paradigma é aplicável ao Direito?, Rio de Janeiro: Lúmen Júris, 2009.

SOUZA CRUZ, Álvaro Ricardo. Hermenêutica jurídica e(m) debate: o constitucionalismo brasileiro entre a teoria do discurso e a ontologia existencial, Belo Horizonte: Fórum, 2007. 